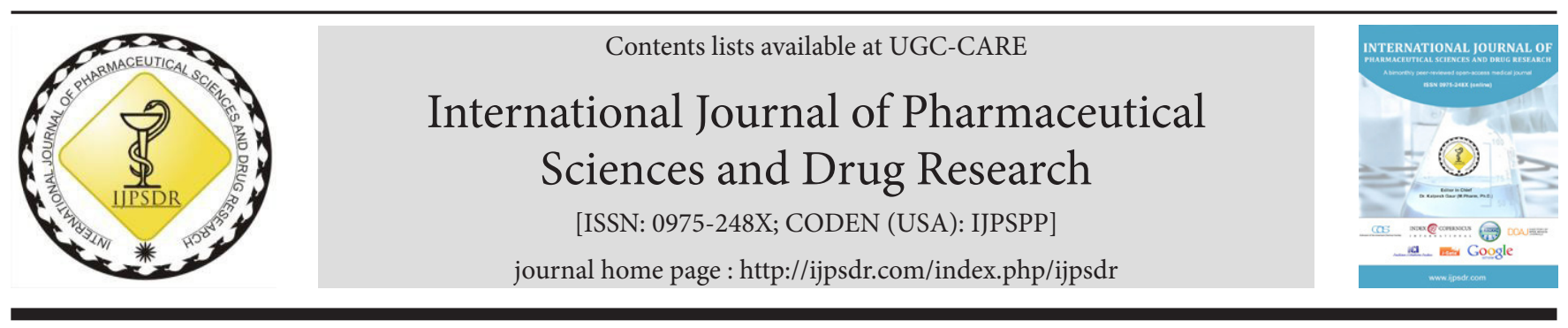

Research Article

\title{
Antiurolithiatic Activity of Natural Constituents Isolated from Aerva lanata Flowers
}

\author{
Subhashini Naikal James Prameela ${ }^{1}$, Shilpika Nagula ${ }^{2^{*}}$ \\ ${ }^{1}$ Department of Chemistry, University College of Science, Osmania University, Hyderabad, Telangana- 500007, India \\ ${ }^{2}$ University College of Technolgy, Osmania University, Hyderabad, Telangana- 500007, India
}

\author{
ART ICLE INFO \\ Article history: \\ Received: 31 August, 2020 \\ Revised: 24 October, 2020 \\ Accepted: 30 October, 2020 \\ Published: 30 November, 2020 \\ Keywords: \\ Aerva lanata, \\ Betulin, \\ In-vitro antiurolithiatic activity, \\ Quercetin. \\ DOI: \\ 10.25004/IJPSDR.2020.120610
}

\begin{abstract}
A B S T R A C T
A well-known traditional herb Aerva lanata, broadly used in India for treatment of different ailments such as urolithiasis. Pashanabheda is used as antiurolithiatic in Ayurveda. In the present study, flowers of $A$. lanata were selected for isolation of active constituents and screening for in vitro antiurolithiatic potentials, as literature supports that flowers have the highest quantity of natural components when compared with the other parts. Hydroalcoholic (80\%-water, $20 \%$-alcohol) extract of A. lanata flowers was prepared and fractionation with different organic solvents.. The two fractions (ethyl acetate and n-butanol) were subjected to isolation of active constituents using column chromatography technique, followed by purification of the isolated constituents by preparative high performance thin layer chromatography (HPTLC)and then the individual components were characterized by IR spectrophotometery. Finally, in vitro antiurolithiatic activity was screened by nucleation and aggregation assay. In the aggregation assay, gradual decrease in the calcium oxalate ( $\mathrm{CaOx}$ ) crystal nucleation as well as growth was observed by light microscopy. The findings of the nucleation assay indicate that phytoconstituents inhibited the crystallization of $\mathrm{CaOx}$ in solution. The size and the number of calcium oxalate crystals decreased with increasing concentration of the phytoconstituents. The increasing concentrations of Quercetin and betulin $(100,200,300,400$ and $500 \mu \mathrm{g} / \mathrm{mL})$ inhibited the CaOx crystal growth. The isolated quercetin and betulin from $A$. lanata have shown antiurolithiatic effect by significantly reducing the $\mathrm{CaOx}$ crystal growth.
\end{abstract}

\section{INTRODUCTION}

Pashanabheda (stone breaking) plants are a group of medicinal plant which is used in Indian traditional medicinal system by ayurvedic practitioners as antiurolithiatic drugs. Traditionally A. lanata (L) is also known as Pashanabheda, belonging to the family Amaranthaceae, used for various medicinal uses including both antiurolithiatic and diuretic activities ${ }^{[1-4]}$ Kidney stones are potential risk factor for chronic kidney disease. The impact of different urinary stone components on renal function is unknown. Patients with urolithiasis have decreased renal function, and the impact of renal function varies depending on the stone components.

Nephrolithiasis or renal stone disease remains a significant health problem in the adult population, with serious medical consequences, throughout a patient's lifetime. The worldwide incidence of urolithiasis is quite high, and more than $80 \%$ of urinary calculi are calcium oxalate stones alone or calcium oxalate mixed with calcium phosphate. $^{[5-7]}$ The present day medical management of nephrolithiasis is either costly or not without side-effects. Invasive procedures for the treatment of nephrolithiasis

\footnotetext{
${ }^{*}$ Corresponding Author: Shilpika Nagula

Address: University College of Technolgy, Osmania University, Hyderabad, Telangana-500007, India

Email $\bowtie$ : shilpika047@gmail.com

Relevant conflicts of interest/financial disclosures: The authors declare that the research was conducted in the absence of any commercial or financial relationships that could be construed as a potential conflict of interest.

Copyright (C) 2020 Subhashini Naikal James Prameela et al. This is an open access article distributed under the terms of the Creative Commons Attribution- NonCommercial-ShareAlike 4.0 International License which allows others to remix, tweak, and build upon the work non-commercially, as long as the author is credited and the new creations are licensed under the identical terms.
} 
may cause serious complications and also impose a great load of costs on the healthcare system. Kidney stones are a potential risk factor for chronic kidney disease. ${ }^{[8,9]}$

The traditional medicine system of India is a rich source of valuable medicinal plant but there is no scientific data reported to establish the activity of these plants. Hence these plant parts need to be evaluated, based on their biological efficacy and chemical constituents for drug development. ${ }^{[10-14]}$ So, we have selected $A$. lanata flowersof India for the present study. The flowers were subjected to bioactivity guided isolation and screening for antiurolithiatic activity to investigate and justify the traditional claim.

The reported phytochemical constituents present in A. lanata are responsible for various biological activities. These constituents include alkaloids (ervine, methylervine, ervoside, aervoside, ervolanine, and aervolanine), flavonoids (kaempferol, quercetin, isorhamnetin, persinol, persinosides A and B), methyl grevillate, lupeol, lupeol acetate benzoic acid, b-sitosteryl acetate and tannic acid. ${ }^{[15-16]}$

Although $A$. lanata is used traditionally by ayurvedic physicians, however, there is no report on the antiurolithiatic potentials by any of the active constituents isolated from A. lanata (L). ${ }^{[17-20]}$ flowers. Hence, this A. lanata (L) flowers were selected to isolate and develop new lead molecules for treating urolithiasis.

\section{Materials AND METHODS}

\section{Collection and Authentication of Plant Part}

The flowers of $A$. lanata were collected from Medchal district, Hyderabad, Telangana. The plant was authenticated by Dr. K. Madhava Chetty, Department of Botany, Osmania University

\section{Physico-Chemical Characterization of $A$. lanata}

Percentage of moisture in the dry powder is calculated using the formula-

$$
\begin{aligned}
(\text { LoD })(\%)= & {[\text { Loss in weight Moisture } / \text { Weight of }} \\
& \text { powder }(\mathrm{g})] \times 100
\end{aligned}
$$

The calculated percentage of moisturewas compared with the pharmacopoeial range.

Ash value percentage was calculated from the dry powder using the formula-

Ash value $=[$ Weight of total of ash/Weight of powder

$$
\text { (g) }] \times 100
$$

The calculated percentage ash value (total ash, water soluble ash and acid insoluble ash) was calculated with the pharmacopoeial range.

\section{Percentage Yield (Extractive Values) for he Fractions}

A total of $200 \mathrm{~g}$ of dried powder was taken for extraction and the total weight of hydro alcohol extract obtained (dried).

\section{Extraction and Fractionation}

The flowers of $A$. lanata were shade dried and then it was grounded to a coarse powder. The powdered dried material was used for the extraction using hydroalcoholic (80\%-water, 20\%-alcohol) and followed by fractionation with different organic solvents such as dichloromethane (fraction I), ethyl acetate (fraction II), n-butanol (fraction III) to separate different groups of polar compounds like flavonoids, triterpenoids and saponins following the technique of liquid- liquid separation. As polar compounds would come in polar solvents, these two fractions (ethyl acetate fraction and n-butanol fraction), which were found to be rich with flavonoids and triterpenoids were subjected to isolation, characterization and in vitro analysis for antiurolithiatic potential. ${ }^{[13-19]}$

\section{Qualitative Phytochemical Tests}

\section{Preparation of Test Solution}

The extract was refluxed with alcoholic solution of potassium hydroxide till complete saponification. The saponified matter extracted with water and unsaponifiable matter extracted with diethyl ether. The ethereal extract was evaporated and the residue (unsaponifiable matter) was subjected to test for steroids, carbohydrates, proteins, flavonoids, glycosides, tannins, phenolic compounds, organic acids, alkaloids, carbohydrates and proteins by dissolving the residue in the chloroform. ${ }^{[21-23]}$

\section{Isolation and Characterization}

Ethyl acetate and n-butanol fractions were subjected to isolation of active constituents using column chromatography technique, followed by purification of the isolated components. The fraction (II) and fraction (III) were loaded separately in the glass column by dissolving in chloroform ( $5 \mathrm{~g}$ in $500 \mathrm{~mL}$ each fraction) and separation was carried out. The fraction II and III were purified by HPTLC technique, followed by the characterization. The individual components were characterized by IR spectrophotometery. ${ }^{[24,25]}$

\section{Column Chromatographic Separation}

A total of $175 \mathrm{~g}$ of silica gel (60-120 mesh) was activated in hot air oven at $110 \pm 1^{\circ} \mathrm{C}$ for one hour. The glass wool was fixed at the bottom of column. The slurry of silica gel was made in the chloroform and loaded in the glass column in small portions with gentle tapping after each addition in order to ensure uniform packing. The small quantity of solvent system was allowed to remain on the top of the column to avoid the drying or cracking of the column. The air bubbles present in the column were removed by gentle tapping to get a uniform bed of adsorbent. The sample was added as a slurry by dissolving in non polar solvent like chloroform on top of the column.different solvents were added in varying proportions above the sample bed to continuously to ensure isolation of active constituents at the bottom. ${ }^{[26-29]}$ 


\section{Thin Layer Chromatography (TLC)}

In this technique, the Silica gel-GF254 was used as an adsorbent and plates were prepared by spreading technique, then air dried and activated for one hour at $110 \pm 5^{\circ} \mathrm{C}$ and used. Separation of components from fractions was carried out using different mobile phases such as methanol, hexane, ethyl acetate, chloroform and water to confirm thepresence of different compounds in the fractions. ${ }^{[28]}$

\section{High Performance Thin Layer Chromatography analysis of fractions (HPTLC)}

HPTLC analysis of fractions was carried out on CAMAG instrument. Sample solutions of fractions II and III were prepared by dissolving $50 \mathrm{mg}$ of sample in $2 \mathrm{~mL}$ of n-hexane and chloroform (1:1). Fractions applied separately on HPTLC plates. Six bands of sample were applied using Linomat V sample applicator on plates (E. Merck, size $10 \times$ $10 \mathrm{~cm}$ ) with the help of Win CATS software programme. ${ }^{[29]}$

Plates were scanned at speed of $20 \mathrm{~mm} / \mathrm{sec}$ using TLC Scanner four at different wavelengths viz. 200, 254, 366 and $430 \mathrm{~nm}$. The chromatograms and $\mathrm{R}_{\mathrm{f}}$ data were collected.

\section{IR Spectroscopic Analysis}

IR spectra of fractions were recorded on Shimadzu IR Affinity-1 (FTIR). The spectra were interpreted for presence of functional groups like hydroxy, keto, epoxy, cyclopropane and cis/trans configuration.

\section{In-Vitro Antiurolithiatic Activity}

\section{Aggregation Assay}

The rate of aggregation of the calcium oxalate crystals was determined by a spectrophotometric assay and by comparing the microscopic Figs of the CaOx crystals. The calcium oxalate monohydrate (COM) crystals were prepared by mixing both the calcium chloride and sodium oxalate solution of $50 \mathrm{~mm}$ each. Both solutions were then equilibrated. The solutions were then cooled to $37^{\circ} \mathrm{C}$ and then evaporated. The COM crystals were then dissolved with $0.5 \mathrm{ml}$ of $0.05 \mathrm{mM}$ Tris buffer and $0.5 \mathrm{ml}$ of $0.15 \mathrm{mM}$ $\mathrm{NaCl}$ solution at $\mathrm{pH} 6.5$ to a final concentration of $1 \mathrm{mg} / \mathrm{mL}$. Absorbance at $620 \mathrm{~nm}$ recorded. The rate of aggregation was estimated by comparing the slope of turbidity in the presence of the extract against control. CaOx crystals, were observed under light microscope $(100 \mathrm{X})^{[30,31]}$.

\section{Nucleation Assay (Turbidity Method)}

A spectrophotometric assay determined the inhibitory activity of the extracts on the nucleation of calcium oxalate crystals. Crystallization was initiated by adding $100 \mu \mathrm{l}$ of $4 \mathrm{mM}$ calcium chloride and $100 \mu \mathrm{l}$ of $50 \mathrm{mM}$ sodium oxalate solutions to $0.5 \mathrm{ml}$ of human normal urine, both prepared in a buffer containing $0.5 \mathrm{ml}$ of 0.05 $\mathrm{mM}$ Tris buffer and $0.5 \mathrm{ml}$ of $0.15 \mathrm{mM} \mathrm{NaCl}$ solution at $\mathrm{pH}$ 6.5 and $37^{\circ} \mathrm{C}$ and adjusted to volume by adding $1.5 \mathrm{~mL}$ of distilled water. The rate of nucleation was determined by comparing the induction time of crystals (time of appearance of crystals that reached a critical size and thus became optically detectable) in the presence of the extract and that of the control with no extract. The optical density (OD) was recorded at $620 \mathrm{~nm}$, and the percentage inhibition calculated as (1-OD (experimental)/ OD (control) $) \times 100 .^{[30,31]}$

\section{RESUlTS AND DiscusSion}

Ash value percentage was calculated from the dry powder of the flower, the calculated percentage ash value (total ash, water soluble ash and acid insoluble ash) was found to be $<5 \%$. Hence the ash value is in the pharmacopoeial range. ${ }^{[32]}$

Percentage of moisture in the dry powder was calculated. The calculated percentage of moisture was found to be $<10 \%$. Hence the moisture is in the pharmacopoeial range. ${ }^{[32]}$

Percentage yield (Extractive values) for the fractions- Total weight of hydro alcohol extract obtained (dried) $12 \mathrm{~g}(6 \%)$ and for fractionation $12 \mathrm{~g}$ dried extract was taken.

Weight of DCM fraction (dried) -2.5g. Percentage yield is $20.8 \%$.

Weight of ethyl acetate fraction (dried)-3.36 g and percentage yield is $28 \%$.

Weight of n-butanol fraction (dried)-3.61g and percentage yield is $30.1 \%$.

Weight of Aqueous extract-2.5g and percentage yield is $20.83 \%$

\section{Phytochemical Investigations by Qualitative Analysis of Extract and Fractions}

Phytochemical investigation showed the presence of primary and secondary plant metabolites in flower extract and fractions. Fraction II and III (ethyl acetate and n-butanol) revealed the presence of steroids, carbohydrates, proteins, flavonoids, saponin glycosides, and phenolic compounds and DCM fraction (I) revealed the presence of alkaloids, carbohydrates, proteins and absence of steroids and flavonoids (Table 1).

\section{Chromatographic Analysis of The Fractions}

HPTLC chromatogram of n-butanol fraction at $366 \mathrm{~nm}$ has showed presence of four peaks with maximum $R_{f}$ value $0.51,0.53,0.89,0.94$. This indicates the presence of probably 4 compounds in the fraction. The chromatograms and $\mathrm{R}_{\mathrm{f}}$ data were collected. HPTLC chromatogram of ethyl acetate fraction at $366 \mathrm{~nm}$ showed presence of two peaks with $\max R_{f}$ value $0.54,0.92$ which shows the presence of probably 2 compounds. ${ }^{[33]}$ (Table 2; Fig. 1 )

\section{Infrared Radiation Spectral Analysis of Fractions}

Infra Red Radiation analysis of fractions II and III (based on phytochemical study results) was carried out using FT-IR Shimadzu IR Affinity-1 (FT IR) spectrophotometer using $\mathrm{KBr}$ pellets technique (Table 3 and Fig. 2). 
Table 1: Various extracts subjected for various phytochemical analysis

\begin{tabular}{|c|c|c|c|c|c|c|c|}
\hline \multirow[b]{2}{*}{ Phytochemicals } & \multicolumn{7}{|c|}{ Different Solvents } \\
\hline & Ethanol & Methanol & Chloroform & Hexane & Ethyl acetate & & Water \\
\hline Flavonoids & - & + & + & + & - & & - \\
\hline Alkaloids & & - & - & - & - & & - \\
\hline Phenol compounds & - & - & - & - & + & & + \\
\hline Tannins & + & - & - & - & - & & - \\
\hline Steroids & - & - & - & - & - & & - \\
\hline Saponins & - & + & + & + & + & & + \\
\hline Terpenoids & - & - & - & - & - & & - \\
\hline Glucosides & - & - & - & + & + & & - \\
\hline \multicolumn{8}{|c|}{ +: The phytochemical is present in the extract; -: The phytochemical is absentin the extract } \\
\hline Fraction & \multicolumn{2}{|l|}{ Mobile phase } & \multicolumn{2}{|l|}{ Obsrvation } & Groups & \multicolumn{2}{|l|}{$R f$} \\
\hline Fraction I & \multicolumn{2}{|c|}{$\begin{array}{l}\text { Methanol: hexane: ethyl acetate: } \\
\text { water }(3.5: 2: 4: 2) \text { Ethyl acetate: } \\
\text { Methanol:Water(3:1.5:1) }\end{array}$} & Two spots (Yellow) & & $\begin{array}{l}\text { Flavanoids } \\
\text { Terpenoids }\end{array}$ & \multicolumn{2}{|l|}{0.7} \\
\hline Fraction II & \multicolumn{2}{|c|}{$\begin{array}{l}\text { Choroform: methanol:water }(6: 3: 0.5) \\
\text { Ethyl acetate: Methanol: } \\
\text { Water(3:1.5:1) }\end{array}$} & $\begin{array}{l}\text { Two spots } \\
\text { (pink) }\end{array}$ & & $\begin{array}{l}\text { Saponins } \\
\text { Terponoids }\end{array}$ & $\begin{array}{l}0.35 \\
0.6\end{array}$ & \\
\hline Fraction III & $\begin{array}{l}\text { Ethyl acetate: } \\
(3: 1.5: 1)\end{array}$ & anol: Water & $\begin{array}{l}\text { Single spot } \\
\text { (Pink) }\end{array}$ & & Terpinoids & 0.3 & \\
\hline
\end{tabular}

Spraying reagents: Iodine and vanillin (5\%)

Table 3: Results of Infrared Radiation Spectral analysis of fractions

\begin{tabular}{ll}
\hline Fraction & Groups/bonds present \\
\hline Fraction II & $\begin{array}{l}\text { Alc OH group Alkane C-H structure carbonyl group } \\
\text { Alkene C=C bond }\end{array}$ \\
Fraction III & $\begin{array}{l}\text { Alkane C-H structure carbonyl group } \\
\text { Alkene C=C structure }\end{array}$ \\
\hline
\end{tabular}

HPTLC chromatogram of fraction II

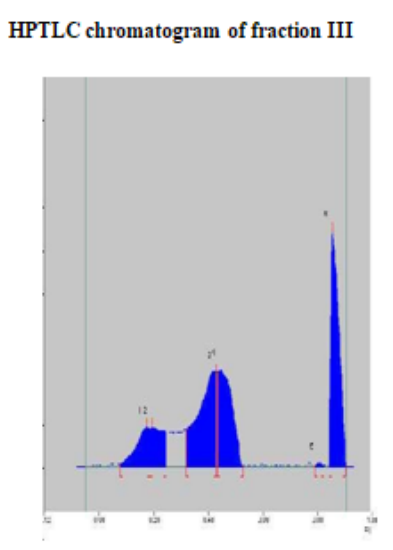

Fig.1: HPTLC chromatograms of Fraction II and III

\section{Aggregation Assay}

Calcium oxalate crystals begins to grow; aggregate with other crystals and retained in the kidney. This is aggregation process which causes renal injury. The extracted components of $A$. lanata demonstrated slightly better results compared to cystone standard solution

\section{IR SPECTRA OF ISOLATED QUERCETIN AND BETULIN}

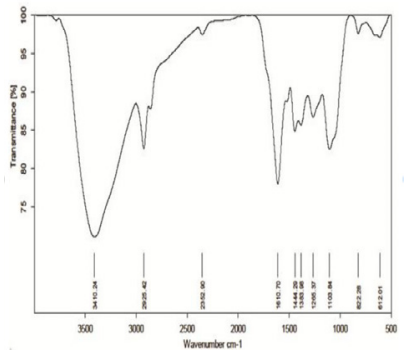

IR spectra of isolated quercetin

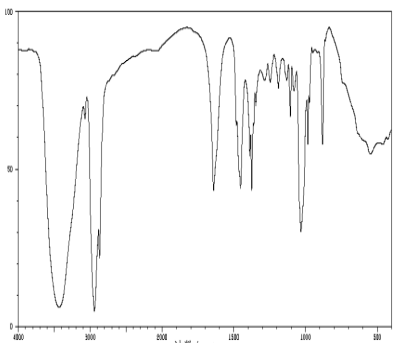

IR spectra of isolated betulin
Fig.2: Charaterization of quercetin and betulin by IR in inhibiting the promoted formation of COD crystals ${ }^{33}$ (Figs 3 and 4).

\section{Nucleation Assay}

Extracted components of $A$. lanata flowers inhibited the crystallization by inhibiting nucleation of calcium oxalate through disintegrating into smaller particles with increasing concentrations of the fraction. The nucleation assay results confirmed that the extract contained nucleation-preventing agents ${ }^{[31-33]}$ (Fig. 5).

\section{DISCUSSION}

In kidney stones formation, calcium oxalate and calcium phosphate or other chemicals in the urine form crystals on kidneys' inner surfaces. This stage is called as initial 


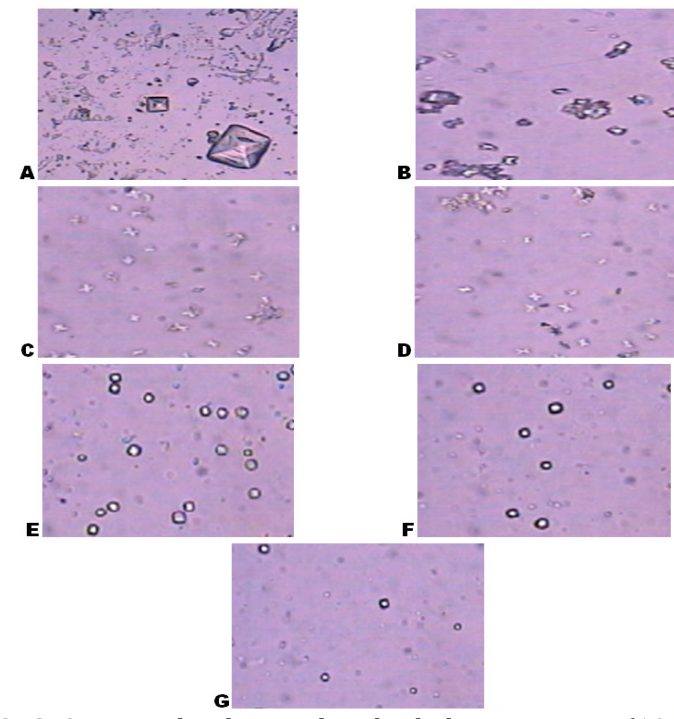

Fig.3: CaOx crystals, observed under light microscope(100X), formed in the metastable solution of $\mathrm{CaOx}$ in the absence

(A) which are larger and the presence of saponin rich fraction of quercetin (B) $10 \mathrm{mg} / \mathrm{mL}$, (C) $20 \mathrm{mg} / \mathrm{mL}$, (D) $40 \mathrm{mg} / \mathrm{ml}$,

(E) $60 \mathrm{mg} / \mathrm{ml}$, (F) $80 \mathrm{mg} / \mathrm{mL}$ and(G) $100 \mathrm{mg} / \mathrm{mL}$ gradually decreases the $\mathrm{CaOx}$ crystals nucleation as well as growth.

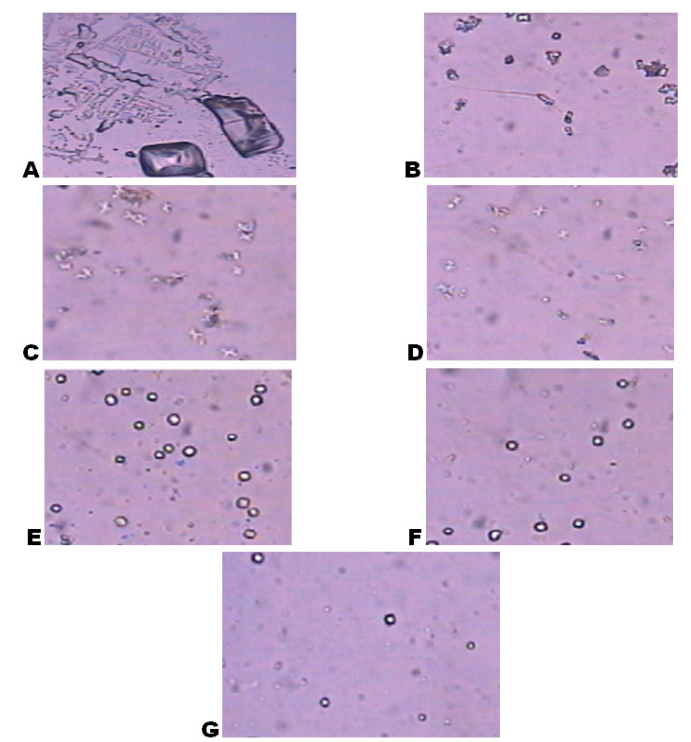

Fig.4: CaOx crystals, observed under light microscope(100X), formed in the metastable solution of $\mathrm{CaOx}$ in the absence

(A) which are larger and the presence of saponin rich fraction of betulin (B) $10 \mathrm{mg} / \mathrm{mL}$, (C) $20 \mathrm{mg} / \mathrm{mL}$, (D) $40 \mathrm{mg} / \mathrm{ml}$, (E) $60 \mathrm{mg} / \mathrm{mL}$, (F) $80 \mathrm{mg} / \mathrm{mL}$ and(G) $100 \mathrm{mg} / \mathrm{mL}$ gradually decreases the CaOx crystals nucleation as well as growth.

mineral phase formation. Over time, crystals may combine to form a small, hard mass called stones and stage is referred to as crystal growth. Calcium oxalate stones have been classified in two types i.e., calcium oxalate monohydrate stones (COM) and calcium oxalate dihydrate stones (COD). Kidney stones are reportedly affecting mankind since long time and have been one of the causes for renal failure. ${ }^{[12,18]}$ As there is no single effective drug available for urolithiasis today, surgery is considered to

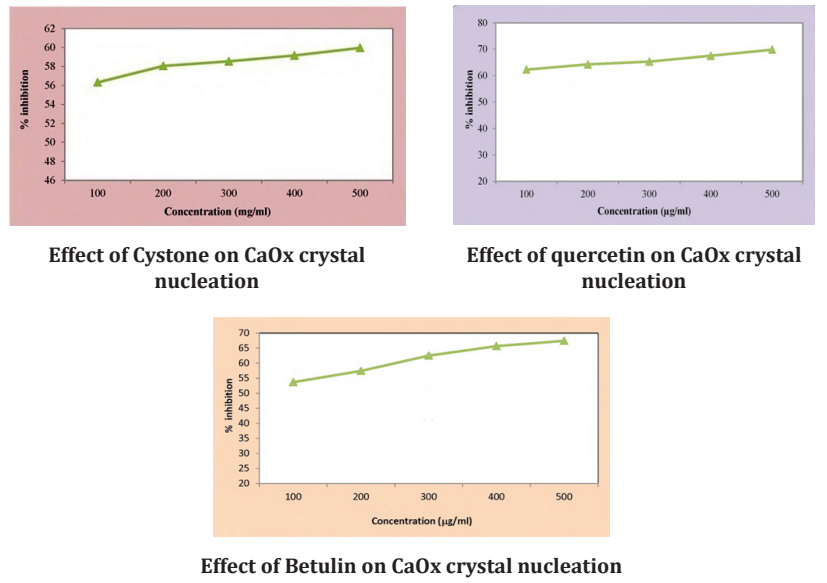

Fig. 5: Effect of Cystone, quercetin and Betulin on CaOx crystal nucleation

be the best option especially when other alternatives fail. However it is expensive and not affordable for common man. Hence the natural drugs are considered to be next alternative.

Calcium oxalate crystals begin to grow; aggregate with other crystals and retained in the kidney. This is aggregation process which causes renal injury. The extracted components of $A$. lanata flowers demonstrated slightly better compared to cystone standard solution to inhibit promoted the formation of COD crystals. COM has a stronger affinity with cell membranes; it may lead to become higher potential risk for renal calculi formation. ${ }^{[13,17]}$ This may be due to high content of saponins present $A$. lanata. The flowers have several polyphenolics, e.g; alkaloids, saponins, phenolics, flavonoids, and other phytoconstituents.

Saponins are well known to have anticrystallization properties by disaggregating the suspension of mucoproteins as crystallization promoters. The isolated components proved to inhibit initial mineral phase formation of calcium phosphate and growth of COM crystals.

Urine supersaturation attributes to calcium oxalate particles crystallization within the urinary tract. ${ }^{[12,17,20]}$ This is nucleation process where stone forming salts begins to unite into clusters with addition of new constituents.

As in vitro crystallization study was performed, since nucleation is an important first step for crystals initiation, then grow and form aggregates. Extracted A. lanata flowers' components inhibited the crystallization by inhibiting nucleation of calcium oxalate by disintegrating into smaller particles with increasing concentrations of the fraction. From the results of the nucleation assay confirmed that the extract contained nucleation-preventing agents.

The present investigation will be supportive as additional information to the scientific evidences regarding in-vitro studies. Since the mechanism of anti-urolithiatic activity in the extract is unknown to date, correlation between in-vitro and in-vivo studies should be further 
investigated to reveal the phytochemicals of the extract which are responsible for dissolving or disintegrating renal calculi and to know better understanding in the molecular mechanism of litholysis. ${ }^{[27,28]}$

This study examined the antiurolithiatic efficacy of the two isolated constituents of $A$. lanata flowers. Based on the bioactivity guided fractionation followed by isolation, these active constituents were characterized as quercetin and botulin. ${ }^{[30-32]}$ These isolated constituents were proved to have potent in vitro anti-urolithiatic activity.

\section{Conclusion}

A. lanata flower extracted phytoconstituents, Quercetin and betulin exhibited significant in-vitro anti-urolithiatic activity. The present study conclusively demonstrates that A. lanata flowers is a good source of various phy tochemicals like flavanoids, triterpenoids and saponins. This study evaluates that antiurolithiatic activity of extracts of $A$. lanata flower is significant. It has given primary evidence for $A$. lanata flower as the plants which possess lithotriptic property. A. lanata flower used in the above study also showed good activity when it was compared with the standard drug cystone.

\section{REFERENCES}

1. Kirtikar K, Basu B. Indian medicinal plant. 2nd ed., vol. II. Dehradun: Inter-national Book Distributors; 2005.

2. Veronika B, Saeed RK. Herbal medicines in the management of urolithiasis: alternative or complementary? Plant parta Medica. 2012;7:1095e103.

3. Ramachandran S, Vijayakumar TM, Saisandeep V, Ramsai K, Dhanaraju MD. Antilithiatic activity of polyherbal extract on ethylene glycol-induced lithiasis in rats. Eur J Biomed Sci. 2011;3:36e9.

4. Nadkarni KM. Indian materia medica, vol. I. Bombay: Popular Prakashan; 1999. p. 49e50.

5. Suman. Herbs: an alternative approach in nephroprotection. Res J Pharna- cognosy Phytochem. 2013;5:15e21.

6. Nagal A, Singla RK. Herbal resources with antiurolithiatic effects: a review. Indo Glob J Pharm Sci. 2013;3:6e14.

7. Patel PK, Patel MA, Saralai MG, Gandhi TR. Antiurolithiatic activity of saponin rich fraction from the fruits of Solanum xanthocarpum Schrad.\&Wendl.(Solanaceae) against ethylene glycol induced urolithiasis in rats. J Ethnopharmacol. 2012;144:160e70.

8. Bhattacharjee A. Phytochemical and ethno-pharmacological profile of Cra-

9. taeva nurvala Buch-Hum (Varuna): a review. Asian Pac J Trop Biomed. 2012;2: 1162e8.

10. Aggarwal S, Tandon C, Forouzandeh M, Singla S, Kiran R, Jethi R. Role of a protein inhibitor isolated from human renal stone matrix in urolithiasis. In- dian J Biochem Biophy. 2005;1:113e7.

11. Ramachandra TV, Suja A. Sahyadri Western ghats-Biodiversity Information System [Internet][2012e2013, Cited 2014]Available from: http://ces.iisc. ernet.in/biodiversity.

12. Deshmukh BS. Ex-situ conservation studies on ethno-medicinal rare, endemic plant species from Western Ghats of Maharashtra. Int J Pharm Bio Sci. 2010;1: 1e5.

13. Peringattulli NK, Decruse SW. Conservation of medicinal plant of
Western Ghats, India and its sustainable utilization through in vitro technology. Vitro Cell Dev Biol Plant. 2011;47:110e22.

14. Adepu A, Narala S, Ganji A, Sapnil C. A review on natural plant: Aerva lanata. Int J Pharma Sci. 2013;3:398e402.

15. Hadjzadeh M, Khoei A, Hadjzadeh Z, Parizady M. Ethanolic extract of Nigella sativa L. seeds on ethylene glycol-induced kidney calculi in rats. Urol J. 2007;4: 86e90.

16. Dinnimath BM, Jalalpure SS. In silico antiurolithiatic screening of Aerva lanata (L) isolated constituents. IJPER. 2015;49:126e33.

17. Sanjib B, Pallab KH. Acute and sub-chronic toxicity study of Trichosanthes dioica root in mice. Am Eurasian J Toxicol Sci. 2013;5:30e5.

18. Atmani F, Slimani Y, Mimouni M, Hacht B. Prophylaxis of calcium oxalate stones by Herniaria hirsuta on experimentally induced nephrolithiasis in rats. BJU Int. 2003;92:137e40.

19. Parmar NS, Prakash Shiv. Screening methodology in pharmacology. New Delhi: Narosa Publishing House; 2006.

20. Karadi RV, Gadge NB, Alagawadi KR, Savadi RV. Effect Moringa oleifera Lam. root-wood on ethylene glycol induced urolithiasis in rats. J Ethnopharmacol. 2006;105:306e11.

21. Gunatilake M. Aerva lanata (Polpala): its effects on the structure and function of the urinary tract. Phcog Res. 2012;4:181e8.

22. Butterweck V, Saeed RK. Herbal medicines in the management of urolithiasis: alternative or complementary? Plant parta Med. 2013;75:1095e103.

23. Velikovic DT, Nikolova MT, Ivancheva SV, Stojanovic JB, Veljkovic VB. Extraction of flavonoids from garden (Salvia officinalis L.) and glutinous (Salvia glutinosa L.) sage by ultrasonic and classical maceration. J Serb Chem Soc. 2007;72:73e80.

24. Kumar R, Kumar T, Kamboj V, Chander H. Pharmacological evaluation of ethanolic extract of Kigelia pinnata fruit against ethylene glycol induced urolithiasis in rats. Asian J Plan Sci Res. 2012;2:63e72.

25. Gadge NB, Jalalpure SS. Curative treatment with extracts of Bombax ceiba L. (Bombacaceae) fruit reduces risk of calcium oxalate urolithiasis in rats. Pharm Biol. 2012;50:338e43.

26. Mohammed T, Amine L, Khadija E, Farouk L, Ibtissam Z, Younes E, et al.Lemon juice has protective activity in a rat urolithiasis model. BMC Urol. 2007;7:18.

27. Siener R, Jahnen A, Hesse A. Influence of a mineral water rich in calcium, magnesium and bicarbonate on urine composition and the risk of calcium oxalate crystallization. Eur J Clin Nutr. 2004;58:270e6.

28. Soundarajan P, Mahesh R, Ramesh T, Hazeena Begum V. Effect of Aerva lanata on calcium oxalate urolithiasis in rats. Indian J Exp Biol. 2006;44:981e6.

29. Doddametikurke RB, Biyani CS, Browning AJ, Cartledge JJ. The role of urinary kidney stone inhibitors and promoters in the pathogenesis of calcium containing renal stones [cited 2012] EAU-EBU Update Ser 2007;5:126e36. available from: www. europeanurology.com.

30. Jawalekar SL, Surve VT, Bhutey A. Effect of dietary habbit \& fluid intake in patients with Urolithiasis. Ann Biol Res. 2013;4:246e51.

31. Kumar R, Kapoor R, Mittal B, Kumar A, Mittal RD. Evaluation of urinary ab-normalities in urolithiasis patients: a study from north India. Indian J Clin Biochem. 2003;18:209e15

32. Gotsman I, Zwas D, Planer D, Admon D, Lotan C, Keren A. The significance of serum urea and renal function in patients with heart failure. Medicine (Bal- timore). 2010;89:197e203.

33. Thangarathinam N, Jayshree N, Mehta AV, Ramanathan L. Effect of polyherbal formulation on ethylene glycol induced urolithiasis. Int J Pharm Pharm Sci. 2013;5:994e7.

34. Geetha K, Venkappayya D, Manavalan R. Beneficial role of b-Amyrin from toothbrush tree Salvadora persica in experimental hyperoxaluria. Asian J Chem. 2010;22:6547e52.

HOW TO CITE THIS ARTICLE: Subhashini NJP, Nagula S. Antiurolithiatic Activity of Natural Constituents Isolated from Aerva lanata Flowers. Int. J. Pharm. Sci. Drug Res. 2020;12(6):668-673. DOI: 10.25004/IJPSDR.2020.120610 